\title{
Hurricanes and the Urban Forest: II. Effects on Tropical and Subtropical Tree Species
}

\author{
Mary L. Duryea, Eliana Kampf, Ramon C. Littell, and Carlos D. Rodríguez-Pedraza
}

\begin{abstract}
In 1998 when Hurricane Georges (177 km/h) crossed over the entire island of Puerto Rico, and in 2004 when Hurricanes Jeanne $(193 \mathrm{~km} / \mathrm{h})$ and Charley $(233 \mathrm{~km} / \mathrm{h})$ struck south Florida, U.S., we measured the impacts of these hurricanes on the urban forest composed of tropical and subtropical species. In addition, we also used previous published data for Hurricane Andrew for some analyses. The percent urban forest loss ranged from 13\% for Georges to $16 \%$ for Jeanne to $18 \%$ for Charley. In Hurricanes Jeanne and Charley, palms survived significantly better than all other trees. Some of the best surviving species in Florida's hurricanes were gumbo limbo (Bursera simarouba), sea grape (Coccoloba uvifera), strangler fig (Ficus aurea), live oak (Quercus virginiana), laurel oak (Quercus laurifolia), and baldcypress (Taxodium distichum). Of the species measured in Puerto Rico, the species with the highest survival and least branch damage were Santa Maria (Calophyllum calaba), Caribbean pine (Pinus caribaea), schefflera (Schefflera actinophylla), and West Indian mahogany (Swietenia mahogani). Losing leaves during these hurricanes had no relationship with how well trees survived. In Hurricanes Jeanne, Charley, and Georges, 3\%, 4\%, and 11\%, respectively, of the trees that fell damaged property. Native tree species survived better than exotic species in Hurricanes Jeanne and Charley but not in Hurricane Georges. Trees growing in groups had greater survival and less branch loss in Hurricane Jeanne than those growing individually. Wood density was not related to survival or branch loss for tree species in Hurricanes Jeanne, Charley, Georges, or Andrew. Two other measurements of wood strength, modulus of elasticity and modulus of rupture, were related to survival and branch loss in Jeanne but not Charley. Tree species with dense crowns had greater survival and less branch loss than moderate- or open-crowned species. Tree species with decurrent growth form survived better than excurrent trees in Hurricane Jeanne with no difference in Charley. Trees with the most rooting space $\left(>7 \mathrm{~m}^{2}\right)$ had the lowest branch loss and the greatest survival in Hurricane Georges. A reanalysis of seven dicot species and their survival in Hurricane Andrew showed that survival for pruned trees was $73 \%$ compared with $47 \%$ for unpruned trees. A survey of 85 arborists, scientists, and urban foresters ranked species for their wind resistance. Using our results from hurricanes and incorporating results from the survey and the scientific literature, we have developed lists of relative wind resistance for tropical and subtropical tree species. These lists are presented with the caveat that no tree is completely windproof and that other factors such as soil conditions, wind intensity, cultural practices, and tree health and age also contribute to wind firmness.
\end{abstract}

Key Words. Rooting space; urban trees; wind; wind resistance; wood density.

Since 1992 when Hurricane Andrew struck south Florida, we have been studying the impacts of hurricanes on tropical and subtropical urban forests (Duryea et al. 1996). In 1998 when Hurricane Georges crossed over the entire island of Puerto Rico and then again in 2004 when Hurricanes Jeanne and Charley struck south Florida, we continued with these urban tree measurements. The urban forest loss for these four hurricanes combined with hurricanes striking the southeastern coastal plain is reported in an accompanying article in this issue (Duryea et al. 2007). Hurricanes striking the subtropical and tropical regions of Florida and Puerto Rico, with their varied wind speeds, gave us the opportunity to study over 60 species and their comparable responses to wind. This study reports on and synthesizes the types of tree damage, possible reasons for damage, and ways to avert damage in the future for tropical and subtropical tree species in urban forests.
When combined with the coastal plain hurricanes and Hurricane Andrew, urban forest loss for eight hurricanes was positively correlated with wind speed $\left(\mathrm{r}^{2}=0.80\right)$ Duryea et al. (2007). The analysis illustrates a nonlinear relationship between urban forest lost and wind speed. The high $\mathrm{r}^{2}$ value indicates that we are able to reasonably predict the urban forest loss given the maximum sustained wind speed of a hurricane.

Studies of hurricane force winds and their impact on trees have centered on natural and plantation forest ecosystems. A handful of studies have looked at tropical and subtropical urban forest responses to wind (Francis and Gillespie 1993; Duryea et al. 1996; Jim and Liu 1997; Francis 2000). The results have indicated that in addition to species differences in wind resistance, other biophysical factors such as topography, soil characteristics, wind speed, tree health, and age determine the response of an urban forest ecosystem to wind. 
The objectives of this study were to analyze the effects of three hurricanes on urban tree species growing in tropical and subtropical regions: (1) to determine if there was speciesspecific damage over the varied wind speeds, and (2) to determine if damage was related to tree attributes (such as size, leaf loss, wood density, and crown) and site characteristics (rooting space and grouped plantings). We then combined these results with previous results from Hurricane Andrew (Duryea et al. 1996), a survey of arborists, urban foresters, and scientists, and the scientific literature to develop windresistant lists and cultural recommendations for tropical and subtropical species.

\section{METHODS}

\section{Urban Tree Measurements}

Urban tree damage was measured after (within 3 to 10 days) the three hurricanes that struck Florida (Charley and Jeanne 2004) and Puerto Rico (Georges 1998) (Duryea et al. 2007). We also include the hurricane response of some tropical/ subtropical species such as live oak (Quercus virginiana) and sabal palm (Sabal palmetto) that occur throughout Florida and were impacted by Hurricanes Erin (1995), Opal (1995), and Ivan (2004) in the Florida panhandle. Hurricane Andrew measurements involved a survey of 128 homeowners in Dade County, Florida, who measured and reported to us about each tree in their yards (Duryea et al. 1996). The methodology for the other hurricanes was the same and is as follows: neighborhoods at the point of landfall of the hurricane were randomly chosen. For each neighborhood, all trees were observed along street transects. For each of the three hurricanes, we sampled 26 neighborhoods and 3,678 trees (Georges), 17 neighborhoods and 2272 trees (Charley), and 7 neighborhoods and 1642 trees (Jeanne). (Branch loss measurements for Hurricanes Frances [2005] and Jeanne were combined and made immediately after Hurricane Jeanne.)

The urban tree measurement methods, the survey methods and the statistical analyses conducted are described in Duryea et al. (2007).

\section{RESULTS AND DISCUSSION \\ Overall Urban Forest Loss}

The percent urban forest loss for these three hurricanes ranged from $13 \%$ for Georges to $16 \%$ for Jeanne to $18 \%$ for Charley. To evaluate tree survival and responses, we divided the species into four categories: palms, dicots, conifers, and Puerto Rico species.

\section{Tree Survival and Branch Loss}

\section{Palms}

Of the palms, sabal palm along with the smaller palms such as areca (Chrysalidocarpus lutescens), Manila (Veitchia merrilii), and pigmy date (Phoenix roebelenii) had $89 \%$ or greater survival (Table 1). In Hurricane Charley, palm survival was $88 \%$ compared with $77 \%$ for all other tree species $(P=0.0001)$. In Hurricane Jeanne, palm survival was $86 \%$ versus $76 \%$ for all other tree species $(P<0.0001)$. When compared with dicots, palms have often been observed to be more resistant to winds (Frangi and Lugo 1991; Francis and Gillespie 1993). Zimmerman et al. (1994) conclude that palms are wind-resistant because they are able to lose all their leaves without losing their terminal meristem. Coconut palm (Cocos nucifera), which survived poorly in Hurricane Andrew (Duryea et al. 1996), exhibited intermediate survival in both Charley's and Georges' winds (77\% survival) (Table 1). Royal palm (Roystonea elata) with only 63\% survival in Andrew had improved survival (87\%) in Hurricane Charley on the deeper soils of the Gulf Coast. Washington palm (Washingtonia robusta) survived well in Charley's $233 \mathrm{~km} / \mathrm{h}$ (145 mph) winds (92\%) but less well in Jeanne's winds of $193 \mathrm{~km} / \mathrm{h}$ (120 mph) (80\%). This was perplexing to us until we looked at the height comparisons of the two populations. Washington palms in the Ft. Pierce area that experienced Hurricane Jeanne averaged $11 \mathrm{~m}$ (36.3 ft) in height with $42 \%$ of the palms above $10 \mathrm{~m}$ (33 ft) compared with an average

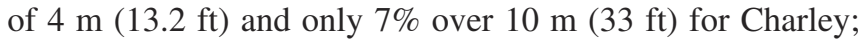
perhaps when Washington palms acquire their heights of 20 $\mathrm{m}(66 \mathrm{ft})$ and above, their wind resistance starts to plummet.

\section{Dicots}

Of the dicot tree species, the poorest surviving species were seen in Hurricane Charley's survival figures with melaleuca (Melaleuca quinquenervia), Australian pine (Casuarina equisitifolia), and black olive (Bucida buceras) (Figures 1A and B). Dicots with highest survival were camphor (Cinnamomum camphora), gumbo limbo (Bursera simarouba), sea grape (Coccoloba uvifera), strangler fig (Ficus aurea), live oak, and laurel oak (Quercus laurifolia). Some species such as camphor, strangler fig, laurel oak, and live oak may continue to stand in hurricane force winds but at the same time lose large branches, especially at the $233 \mathrm{~km} / \mathrm{h}(145 \mathrm{mph})$ winds of Charley (Figure 2). After intermediate survival in Hurricane Andrew, West Indian mahogany (Swietenia mahagoni) and white cedar (Tabebuia heterophylla) exhibited higher survival in Hurricane Georges at $177 \mathrm{~km} / \mathrm{h}$ (110 mph). After relatively poor survival in Andrew, $94 \%$ of the royal poinciana (Delonix regia) survived the relatively lighter winds of Hurricane Georges. In a study of 24 species of urban trees in San Juan, Puerto Rico, after Hurricane Georges, species with the highest survival (lowest failed stems) were West Indian mahogany (100\%), mango (Mangifera indica) (98\%), queen's crapemyrtle (Lagerstroemia speciosa) (98\%), and royal poinciana (98\%) (Francis 2000). Species with the poorest survival were African tuliptree (Spathodea campanulata) (66\%) and weeping banyan (Ficus benjamina) (70\%) (Francis 2000). Studies summarized in Everham and Brokaw's 
Table 1. Survival (percent of trees standing after the hurricane) of tropical/subtropical tree species after the three hurricanes reported in this study and Hurricane Andrew ${ }^{2}$.

\begin{tabular}{|c|c|c|c|c|}
\hline \multirow[b]{2}{*}{ Tree species } & \multicolumn{4}{|c|}{ Survival (\%) after each hurricane (wind speed in $\mathrm{km} / \mathrm{h} ; \mathrm{mph}$ ) } \\
\hline & $\begin{array}{l}\text { Georges } \\
(177 \mathrm{~km} / \mathrm{h} ; 110 \mathrm{mph})\end{array}$ & $\begin{array}{l}\text { Jeanne } \\
(193 \mathrm{~km} / \mathrm{h} ; 120 \mathrm{mph})\end{array}$ & $\begin{array}{l}\text { Charley } \\
(233 \mathrm{~km} / \mathrm{h} ; 145 \mathrm{mph})\end{array}$ & $\begin{array}{l}\text { Andrew } \\
(265 \mathrm{~km} / \mathrm{h} ; 165 \mathrm{mph})\end{array}$ \\
\hline \multicolumn{5}{|l|}{ Dicots } \\
\hline Araucaria heterophylla & 88 & - & 74 & - \\
\hline Bucida buceras & 84 & - & 57 & 68 \\
\hline Bursera simarouba & - & - & 89 & 84 \\
\hline Callistemon viminalle & - & - & - & 52 \\
\hline Carya floridana & - & 83 & - & - \\
\hline Casuarina equisitifolia ${ }^{\mathrm{y}}$ & - & - & 57 & 4 \\
\hline Cinnamomum camphora ${ }^{\mathrm{x}}$ & - & - & 90 & - \\
\hline Citrus spp. & - & 67 & 74 & 25 to 66 \\
\hline Coccoloba uvifera & - & - & 84 & 64 \\
\hline Delonix regia $\left({ }^{\mathrm{w}}\right.$ in $\left.\mathrm{s} . \mathrm{FL}\right)$ & 94 & - & - & 57 \\
\hline Eugenia foetida & - & - & - & 96 \\
\hline Ficus aurea & - & - & 84 & - \\
\hline Mangifera indica & 76 & - & - & 60 \\
\hline Melaleuca quinquenervia ${ }^{y}$ & 65 & 75 & 45 & 79 \\
\hline Persea americana & - & - & - & 46 \\
\hline Quercus geminata & - & 94 & - & - \\
\hline Quercus laurifolia & - & 94 & 86 & - \\
\hline Quercus virginiana & - & 97 & 78 & 78 \\
\hline \multicolumn{5}{|l|}{ Schefflera actinophylla } \\
\hline$\left({ }^{\mathrm{x}}\right.$ in central and south FL) & 87 & - & - & 85 \\
\hline Swietenia mahagoni & 92 & - & - & 75 \\
\hline Tabebuia heterophylla & 83 & - & - & 72 \\
\hline \multicolumn{5}{|l|}{ Monocots_Palms } \\
\hline Chrysalidocarpus lutescens & 94 & - & 97 & 93 \\
\hline Cocos nucifera & 77 & - & 77 & 41 \\
\hline Phoenix reclinata $\left({ }^{\mathrm{X}}\right.$ in s. $\left.\mathrm{FL}\right)$ & - & - & 100 & - \\
\hline Phoenix roebelenii & - & 100 & 100 & - \\
\hline \multicolumn{5}{|l|}{ Roystonea elata } \\
\hline (R. borinquena in $\mathrm{PR}$ ) & 93 & - & 87 & 63 \\
\hline Sabal palmetto & - & 92 & 92 & 93 \\
\hline Syagrus romanzoffiana & - & 74 & 69 & 42 \\
\hline Veitchia merrilii & 89 & - & 95 & - \\
\hline Washingtonia robusta & - & 80 & 92 & - \\
\hline \multicolumn{5}{|l|}{ Conifers } \\
\hline Pinus clausa & - & 4 & - & - \\
\hline Pinus elliottii var. Densa & & & & \\
\hline (P. caribaea in $\mathrm{PR})$ & 89 & 90 & 79 & 73 \\
\hline Pinus palustris & - & - & 57 & - \\
\hline Taxodium distichum & - & - & 95 & - \\
\hline
\end{tabular}

${ }^{\mathrm{z}}$ Numbers are only presented for tree species having a sample size greater than 20 trees for each hurricane. Least significant differences at $P=0.05$ are $16 \%$ for Georges, 35\% for Jeanne, and 30\% for Charley; Andrew survival percentages are from Duryea et al. 1996.

${ }^{y}$ Prohibited from use in Florida.

${ }^{\mathrm{x}}$ Invasive and not recommended for use in Florida.

${ }^{\mathrm{w}}$ Caution: may be used but manage to prevent escape in Florida (Fox et al. 2005).

table of species resistance to catastrophic wind (1996) rank gumbo limbo, mahogany, sea grape, baldcypress (Taxodium distichum), live oak, and white cedar with high wind resistance in at least two or more studies. Species that received the lowest wind-resistant ratings in two or more studies were
Australian pine (Casuarina equisetifolia), Honduras mahogany (Swietenia macrophylla), swamp mahogany (Eucalyptus robusta), and Caribbean pine (Pinus caribaea).

In the urban areas of the southeastern coastal plain, laurel oak trees did not survive as well as live oak and sand live oak 


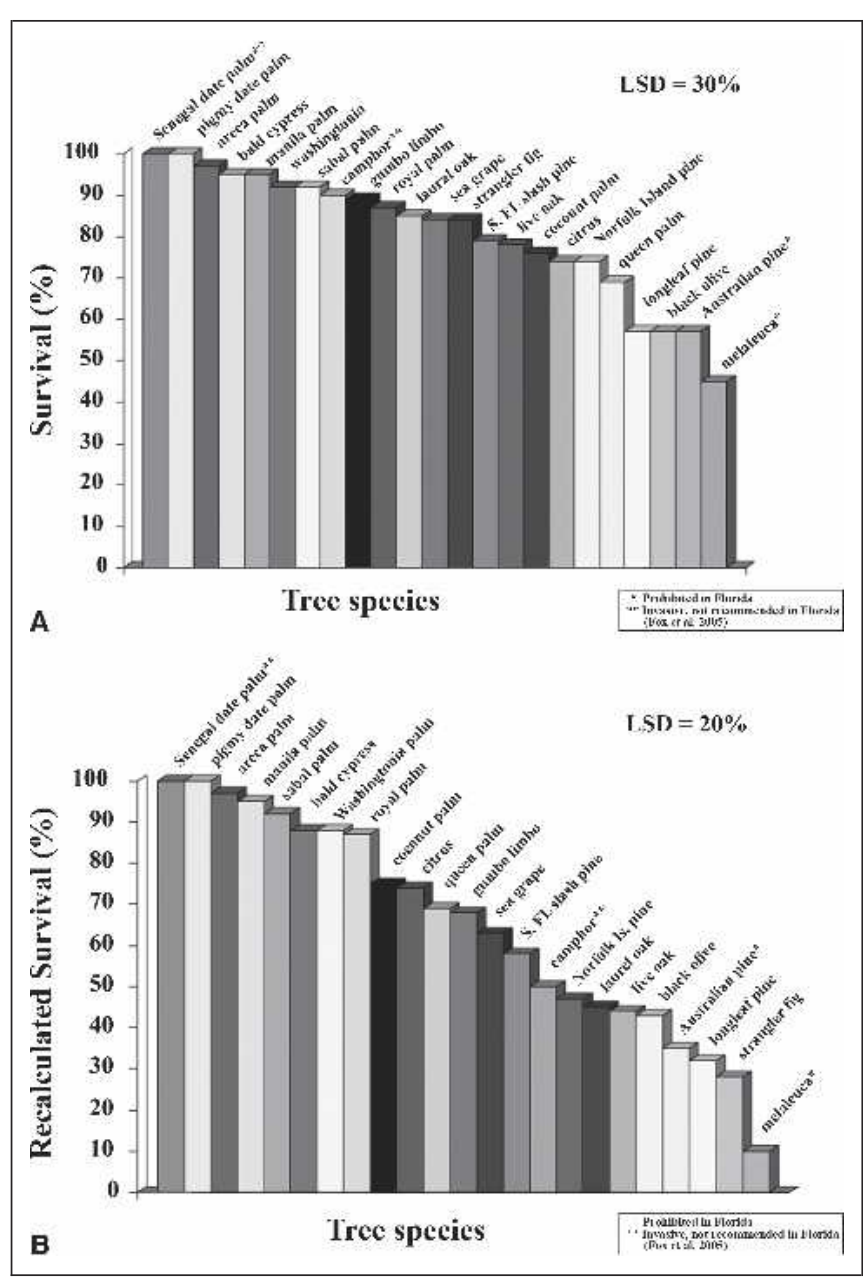

Figure 1. (A) Survival (percent) of tree species in Hurricane Charley, which struck at $233 \mathrm{~km} / \mathrm{h}$ (145 mph). (B) A recalculation of survival (percent) after considering trees with $\geq 50 \%$ branch loss as dead after Hurricane Charley. The reported least significant difference (LSD) is at the 0.05 level.

(Quercus geminata) in four hurricanes (Duryea et al. 2007). However, in the two south Florida hurricanes, both survival and branch loss for these oaks were similar (Figures 1 and 2). We also compared large trees of these species (greater than $50 \mathrm{~cm}$ diameter) and found that their survival, branch loss, and recalculated survival were not significantly different in Jeanne and Charley. Speculations about the reasons for lack of difference between live oak and laurel oak in south Florida include: (1) laurel oak in south Florida may be a different cultivar or variety than those in north Florida, and (2) sandier soils in south Florida and their accompanying lower site quality may result in laurel oaks with shorter heights or lower height-to-diameter ratio (as occurs between the north Florida and south Florida varieties of slash pine [Pinus elliottii var. elliottii and var. densa]). Still, many authors point to live oak as a tree with strong wood and little failure in hurricanes (Touliatos and Roth 1971; Swain 1979; Hook et al. 1991; Barry et al. 1993).

\section{Conifers}

Of the conifer species, baldcypress survived Hurricane Charley the best with 95\% survival (Figure 1A). Baldcypress also experienced little damage after Hurricane Hugo (Gresham et al. 1991; Putz and Sharitz 1991). After Hurricane Andrew, cypress in the Everglades National Park was still standing on the edges of the hammocks, whereas many hardwoods had failed (Orr and Ogden 1992). Only 4\% of the sand pine (Pinus clausa) survived Hurricane Jeanne; sand pine's poor survival has been measured in several other hurricanes (Duryea, 1997; Duryea et al. 2007). South Florida slash pine is next best in wind resistance for the conifers across the south Florida hurricanes but longleaf pine (Pinus palustris), which is usually similar to slash pine in wind resistance in the coastal plain hurricanes (Duryea et al. 2007), had 57\% survival in Hurricane Charley. Survival of south Florida slash pine in Pine Rockland ecosystems ranged from $78 \%$ to $88 \%$ in Hurricane Andrew. Mortality of the standing pine trees continued for 1 year with $17 \%$ to $25 \%$ dying (Platt et al. 2000). We returned 3 months after Hurricane Charley and found that $27 \%$ of the standing south Florida slash pines and $48 \%$ of the standing longleaf pines had died.

\section{Puerto Rico Species}

Of the species measured in Puerto Rico, the species with the highest survival and least branch damage were Santa Maria (Calophyllum calaba), Caribbean pine, schefflera, West Indian mahogany, and Oriental arborvitae (Thuja orientalis) (Table 2). Many trees had extensive branch loss that reduced

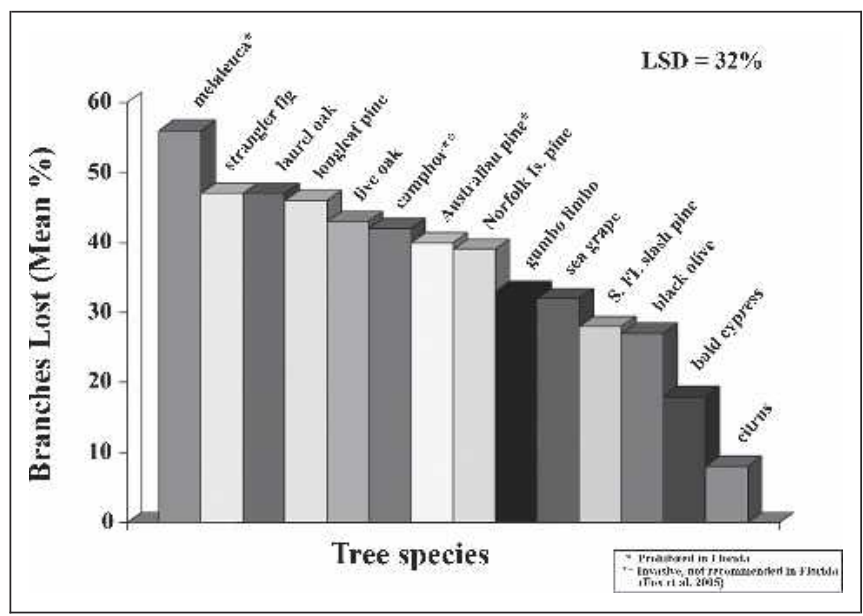

Figure 2. Branch loss (percent) for each tree species in Hurricane Charley, which struck land at $233 \mathrm{~km} / \mathrm{h}$ (130 $\mathrm{mph}$ ). The reported least significant difference is at the 0.05 level. 
Table 2. Survival and branch loss of tree species (excluding palms, see Table 1) in Puerto Rico after Hurricane Georges (110 mph).

\begin{tabular}{|c|c|c|c|c|}
\hline Tree species & Sample size & Survival (\%) & Branch loss $(\%)$ & Recalculated survival (\%) \\
\hline Araucaria heterophylla & 25 & 88 & 41 & 52 \\
\hline Bauhinia monandra & 31 & 71 & 41 & 39 \\
\hline Bucida buceras & 286 & 84 & 33 & 59 \\
\hline Callistemon citrinus & 42 & 81 & 12 & 69 \\
\hline Calophyllum calaba ( ${ }^{\mathrm{w}}$ in south FL) & 295 & 93 & 20 & 81 \\
\hline Cassia javanica & 28 & 86 & 42 & 57 \\
\hline Cassia siamea & 94 & 85 & 53 & 30 \\
\hline Crescentia cujete & 21 & 67 & 12 & 62 \\
\hline Cupressus sempervirens & 31 & 29 & 7 & 29 \\
\hline Delonix regia $\left({ }^{\mathrm{w}}\right.$ in $\left.\mathrm{s} . \mathrm{FL}\right)$ & 194 & 94 & 33 & 68 \\
\hline Enterolobium cyclocarpum & 20 & 100 & 23 & 85 \\
\hline Eucalyptus robusta & 69 & 86 & 59 & 28 \\
\hline Ficus benjamina & 65 & 83 & 25 & 63 \\
\hline Ficus macrocarpa & 33 & 76 & 18 & 67 \\
\hline Ficus microcarpa $\left({ }^{\mathrm{x}}\right.$ in central and south FL) & 22 & 100 & 25 & 73 \\
\hline Hibiscus elatus & 25 & 100 & 63 & 20 \\
\hline Lagerstroemia speciosa & 138 & 88 & 28 & 70 \\
\hline Mangifera indica & 76 & 76 & 36 & 51 \\
\hline Melaleuca quinquenervia ${ }^{\mathrm{y}}$ & 37 & 65 & 21 & 57 \\
\hline Melicoccus bijugatus & 22 & 82 & 25 & 64 \\
\hline Pinus caribaea & 53 & 89 & 16 & 85 \\
\hline Pterocarpus indicus & 32 & 97 & 29 & 75 \\
\hline Pterocarpus macrocarpus & 43 & 95 & 33 & 77 \\
\hline Schefflera actinophylla ( ${ }^{\mathrm{x}}$ in central and south FL) & 24 & 88 & 17 & 79 \\
\hline Spathodea campanulata & 24 & 67 & 52 & 37 \\
\hline Swietenia mahagoni & 146 & 92 & 21 & 80 \\
\hline Swietenia macrophylla & 69 & 74 & 28 & 64 \\
\hline Swietenia macrophylla $\times$ mahagoni & 36 & 89 & 43 & 58 \\
\hline Tabebuia heterophylla & 334 & 83 & 26 & 65 \\
\hline Terminalia cattapa $\left({ }^{\mathrm{w}}\right.$ in south FL) & 44 & 89 & 35 & 52 \\
\hline Thuja orientalis & 36 & 92 & 16 & 86 \\
\hline Least significant difference, $P=0.05$ & - & 16 & 21 & 23 \\
\hline
\end{tabular}

${ }^{\mathrm{z}}$ Recalculated survival was calculated by subtracting trees with $\geq 50 \%$ branch loss. Numbers are only presented for tree species having a sample size greater than 20 trees for each hurricane.

${ }^{y}$ Prohibited from use in Florida.

${ }^{\mathrm{x}}$ Invasive and not recommended for use in Florida.

${ }^{\text {w}}$ Caution: may be used but manage to prevent escape in Florida (Fox et al. 2005).

survival further with the most notable species being Norfolk Island pine (Araucaria heterophylla), Napoleon's plume (Bauhinia monandra), apple blossom (Cassia javanica), yellow cassia (Cassia siamea), swamp mahogany, mahoe ( $\mathrm{Hi}$ biscus elatus), and African tuliptree. The 24 tree species measured in Francis' study (2000) after Hurricane Georges also showed extensive branch damage ranging from $23 \%$ to $81 \%$. Similar to our study, Francis also found that West Indian mahogany was the best survivor (100\% survival) and had the least branch loss, whereas African tuliptree experienced the most crown loss and was one of the poorest survivors (66\% survival) (Francis 2000). Black olive and royal poinciana also had similar results to our study with trees surviving well (98\%) but losing nearly half of their branches.

\section{Broken versus Uprooted}

Some species have a tendency to break at the main stem compared with uprooting. South Florida slash pine mostly broke at the main stem in Jeanne (64\% broke) and Charley (76\%). In Hurricane Andrew, 90\% of the south Florida slash pine that fell broke (Duryea et al. 1996). Van Hooser and Hedlund (1969) also found that pines tended to snap compared with uprooting for broadleaf species. Seventy-one percent of the sand pine broke in Jeanne yet in Ivan sand pine uprooted (Duryea et al. 2007). Live oak with its dense wood tended to uproot (63\% uprooted) compared with laurel oak in where $80 \%$ of the trees broke. Walker (1991) also noted less breakage with higher-density wood species. Palms mostly uprooted in our study (in Hurricane Charley, coconut had 
59\% uprooted; royal, 100\%; sabal, 67\%; and queen [Syagrus romanzoffiana], $81 \%$ uprooted).

\section{Property Damage}

In Hurricanes Jeanne and Charley, only 3\% and $4 \%$ of the trees that fell damaged property. In Jeanne, all of this damage was to major property (houses, power lines, or docks), and the only two species with more than $3 \%$ of their fallen trees causing damage were sand and south Florida slash pines. In Charley, half of the damage ( $2 \%$ out of a total of $4 \%$ of the fallen trees) was to major property (houses or power lines) and there were no dominant species causing damage.

Eleven percent of the trees that fell damaged property in Hurricane Georges. Of these, $27 \%$ damaged major property (houses, power lines, screened enclosures, automobiles, and so on) and $73 \%$ damaged minor property (fences, sheds, sidewalks). The only tree species that caused more than $3 \%$ damage was swamp mahogany. With $20 \%, 21 \%$, and $8 \%$ of the trees that fell causing property damage in Hurricanes Ivan, Erin, and Opal, respectively, it appears that falling trees cause more damage in these north Florida hurricanes than in south Florida (Duryea 1997; Duryea et al. 2007); this could be attributable to the increased urban forest canopy in north Florida and the poor health and aged condition of trees such as laurel oaks, water oaks, and pecans.

\section{Direction of Fall}

To investigate the direction that trees fell in Hurricane Andrew, we conducted a $\chi^{2}$ analysis using species with sample sizes larger than 20 trees $(n=318$ trees). We found that most trees fell to the west (48\%) followed by south $(21 \%)$ and the southwest (15\%). These three directions totaled $83 \%$ of the fallen trees and were significantly different than the total of all the other directions, which encompassed $17 \%$ of the trees $(P=0.0001)$.

\section{What Makes a Tree More Wind-Resistant?}

The goal of this research project is to attempt to determine what biological and cultural factors make trees more or less wind-resistant. By evaluating these factors, we can better understand the differences between species (i.e., whether they have dense wood or defoliate quickly in wind) and between certain practices (such as rooting space or planting trees in groups compared with individual tree plantings), which could result in a healthier and more wind-resistant urban forest.

\section{Defoliation}

In a logistic regression with survival as the response variable and leaves (percent lost) as the explanatory variable, leaf loss had no relationship with survival in Hurricanes Jeanne, Charley, or Georges. This is in contrast to Hurricane Ivan in which southeastern coastal plain tree species that lost more leaves also survived better (Duryea et al. 2007). Losing leaves and reducing the wind drag or resistance from the crown may be a strategy for some species and not for others.

\section{Native and Exotic Species}

Native tree species survived better in Hurricanes Jeanne, Charley, and Andrew but not in Hurricane Georges (Figure 3). Native species also lost fewer branches than exotic species in Jeanne ( $21 \%$ versus $36 \%, P=0.0001)$ and Charley $(36 \%$ versus $39 \%, P=0.0001)$. Some of the exotic species with low survival were melaleuca, Australian pine, and queen palm and these can be compared with native species with high survival: live oak, gumbo limbo, and sabal palm. In their extensive review of hurricanes and forest damage, Everham and Brokaw (1996) summarize that there is a trend toward more damage in exotic forest plantations, although they also point out that these exotic forests are often monocultures. Of the 35 tree species measured after Hurricane Georges in Puerto Rico $(n \geq 20)$, only four were native trees to Puerto Rico: Santa Maria, black olive, white cedar, and common calabash tree (Crescentia cujete). Santa Maria survived very well (93\%) but the other three had $84 \%, 83 \%$, and $67 \%$, not surviving better than many of the exotic species (Table 2). Branch loss of exotics and natives in Puerto Rico, too, appeared to be equal (31\% for exotics versus $27 \%$, not significant). With few exotic species in the urban forest population, natives also did not survive better in the southeastern United States Coastal Plain during Hurricane Ivan (Duryea et al. 2007).

\section{Trees Growing in Groups}

We asked the question whether trees growing in groups or clusters, as compared with singly, might survive hurricane

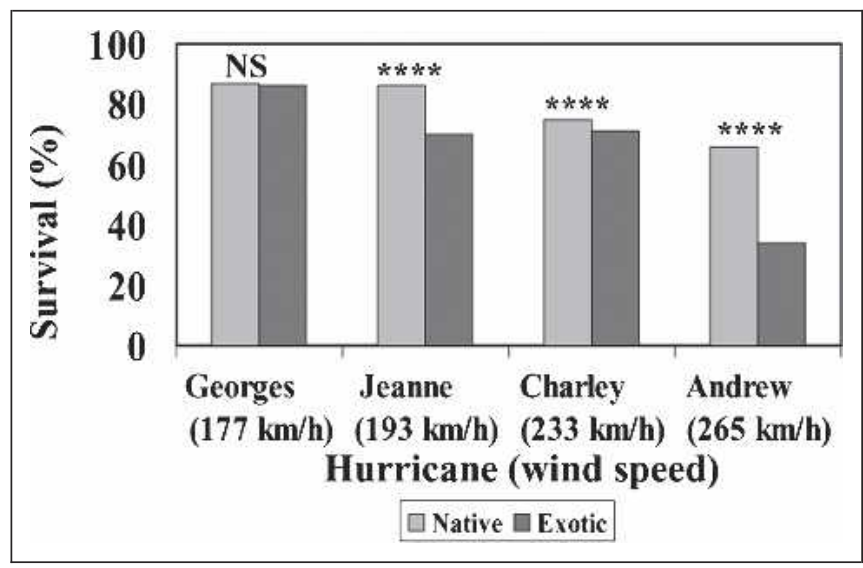

Figure 3. Survival of native trees compared with exotic trees for Hurricanes Georges (Puerto Rico), Jeanne, Charley, and Andrew (south Florida). (N.S. means survival of native trees is not significantly different than exotic trees for Georges; ${ }^{* * *}$ means survival is significantly different for native trees compared with exotic trees at the $P<$ 0.0001 level.) 
force winds better. A group was defined as five or more trees each growing within $3 \mathrm{~m}(9.9 \mathrm{ft}$ ) of another tree (but not in a row), and we measured this site characteristic for Hurricane Jeanne. Trees growing in groups had $88 \%$ survival during Hurricane Jeanne compared with $78 \%$ for those growing as individual trees $(P=0.0001)$. In addition, trees growing in groups had less branch loss than individual trees (19\% versus $27 \%, P=0.09$ ). Trees in groups also survived Hurricane Ivan better than individual trees (Duryea et al. 2007).

\section{Wood Characteristics}

Wood density was not related to survival or branch loss for tree species in Hurricanes Jeanne, Charley, Georges, or Andrew. Species with low wood densities $\left(0.31\right.$ and $\left.0.42 \mathrm{~g} / \mathrm{cm}^{3}\right)$ and high survival rates in these hurricanes are gumbo limbo and baldcypress. Australian pine and melaleuca with low survival in all the hurricanes have high wood densities of 0.83 and $0.65 \mathrm{~g} / \mathrm{cm}^{3}$. In Jeanne, for example, melaleuca with its relatively high wood density had the lowest survival (22\%) and the highest branch loss $(60 \%)$ of all the species. This lack of relationship between tree survival and wood density is in contrast to many studies in which species with denser wood are less likely to fail in hurricanes (Putz et al. 1983; Webb 1989; Zimmerman et al. 1994; Francis 2000; Duryea et al. 2007). Francis and Gillespie (1993) spoke about exceptions of these positive effects of wood density by citing examples of trees species (balsa, Ochroma pyramidale and yagrumo, Cecropia schreberiana) that have light weak wood but survived better in Hurricane Hugo compared with pitch apple (Clusia rosea) and Australian pine that have strong wood but experienced trunk snap and major branch breakage. However, King (1986) noted that the flexibility and strength conferred by high wood density give trees the ability to resist winds.

Here it is important to point out that different strategies are most likely at work for different species. Everham and Brokaw (1996) emphasize that species differences do exist and they are probably explained by difference in canopy architecture, wood density, bole shape, rooting patterns, and susceptibility to disease. Also they point out that these differences may be obscured by difference in exposure, soil, or silvicultural (cultural) treatments.

Two other measurements of wood strength are the modulus of elasticity (Young's elastic modulus) and the modulus of rupture. The modulus of elasticity measures the wood's stiffness; after applying a certain weight (in MPa), it measures whether the wood recovers to its original position (Reyes et al. 1992; Forest Products Laboratory 1999; Niklas 1999). Tree species with the highest modulus of elasticity (oaks and south Florida slash pine, all above 9,600 MPa) survived Hurricane Jeanne better and lost fewer branches than the one species with the lowest values (sand pine with 7,000 MPa) $(P=0.05)$. However, the modulus of elasticity had no relationship to tree species survival or branch loss in the stronger
$233 \mathrm{~km} / \mathrm{h}$ (145 mph) winds of Hurricane Charley; two species with the lowest modulus of elasticity are gumbo limbo and baldcypress, and these species experienced the highest survival and nearly the lowest branch loss.

Modulus of rupture is a measure of the bending stress that wood can experience without mechanically failing (Forest Products Laboratory 1999; Niklas 1999). Again, sand pine with the lowest modulus of rupture experienced significantly $(P=0.05)$ lower survival and higher branch loss than the other species (oaks and south Florida slash pine). In Hurricane Ivan, survival was also higher for those species with the highest modulus of rupture, and branch loss showed no relationship (Duryea et al. 2007). In Hurricane Charley, there appeared to be no relationship with the lowest modulus of rupture for baldcypress $(46,000 \mathrm{kPa})$ and the highest for live oak $(82,000 \mathrm{kPa})$, whereas baldcypress had the highest survival $(95 \%)$ and lowest branch loss (18\%) compared with live oak's $78 \%$ survival and $43 \%$ branch loss.

\section{Crown Characteristics}

Crown density is an estimate of the openness of the crown or the ratio of positive and negative space within the crown (Hightshoe 1988; Gilman 2005). We determined from the literature and observation the density class of each species and then compared open with moderate with dense crowns for branch loss and survival (Hightshoe 1988; Gilman 2005). In Hurricane Charley, dense crowns had significantly greater survival than moderate crowns ( $78 \%$ versus $64 \% ; P=0.02$ ) but were not different than open crown survival $(75 \%)$. Branch loss was also greatest for moderate crown density trees $(45 \%$ versus $36 \%$ and $34 \%$ for dense and open, $P=$ 0.08 and $P=0.02$ ), and the recalculated survival (subtracting the trees with greater than $50 \%$ branch loss) was the poorest for trees with moderate crown densities (37\%). In Hurricane Jeanne, again dense-crowned trees survived better $(88 \%)$ than $(79 \%)$ moderate, which survived better than open trees $(47 \%, P$ ranged from 0.05 to 0.0001$)$. Branch loss was the greatest for moderate $(43 \%)$, then open $(33 \%)$, and the least with dense-crowned species (19\%) $(P$ ranged from 0.05 to 0.0001). Dense-crowned trees include citrus, black olive, laurel oak, sand live oak, and live oak. Moderate density trees included sea grape, Florida scrub hickory, and melaleuca. Open-crowned trees include gumbo limbo, Australian pine, Norfolk Island pine, baldcypress, and the pines. In contrast to our results, Everham and Brokaw (1996) in their review of hurricanes and trees discuss the tendency for dense-crowned trees to be more damaged in hurricanes compared with trees with more open-foliaged crowns. In agreement with this study's results, in our study of southeastern coastal plain species, dense crowns also survived better but lost more branches (Duryea et al. 2007).

The growth form of a tree can be categorized as excurrent or decurrent. Excurrent trees have strong apical dominance 
with the main trunk present throughout the life of the tree (giving rise to cone-shaped crowns with a central trunk). Decurrent trees have lateral branches, which grow as rapidly as the central trunk; they have no dominant main leader (Harris et al. 2004). Excurrent and decurrent trees had equal survival and branch loss in Hurricane Charley. When survival was recalculated (subtracting the trees that had $50 \%$ or greater branch loss), decurrent trees survived slightly better than excurrent trees (52\% versus $45 \%, P=0.06$ ). In Hurricane Jeanne, decurrent trees survived better $(87 \%$ versus $56 \%, P<0.0001)$ and lost fewer branches $(21 \%$ versus $42 \%$, $P<0.0001)$ than excurrent trees. Typical excurrent trees are Norfolk Island pine, baldcypress, melaleuca, Australian pine, and the pines. Decurrent trees include black olive, citrus, sea grape, strangler fig, Florida scrub hickory, and the oaks. Some authors have noted that crown shape may influence how trees respond to wind (Curtis 1943; Skatter and Kucera 2000; Niklas 2002). In a study of cherry trees, Niklas and Spatz (2000) stated that their results showed that stem taper and canopy size and shape appear to influence stress levels to trees from wind.

\section{Rooting Space}

Giving trees enough rooting space is important for both tree health and anchorage. In Hurricane Georges, we measured rooting space and compared it with survival and branch loss. Trees with the most rooting space $\left(>7 \mathrm{~m}^{2}\right)$ had the lowest branch loss and the greatest recalculated survival (Table 3). When discussing soil conditions, Everham and Brokaw (1996) summarize many papers on soil and wind by saying that soil conditions that restrict root development and anchorage lead to more tree and forest damage in wind.

\section{Pruning}

After Hurricane Andrew, we reported that gumbo limbo, live oak, and black olive had better survival if they had previously been correctly pruned (Duryea et al. 1996). We reanalyzed these data using the dicot tree species that had a sample greater than 20 trees (including a total of 371 trees) - black olive, gumbo limbo, bottlebrush (Callistemon viminalis), royal Poinciana, live oak, West Indian mahogany, and white

Table 3. Survival and branch loss in Hurricane Georges for trees growing in different amounts of rooting space ${ }^{z}$.

\begin{tabular}{lllll}
\hline $\begin{array}{l}\text { Rooting } \\
\text { space } \\
\left(\mathrm{m}^{2}\right)\end{array}$ & $\begin{array}{l}\text { Sample size for } \\
\text { survival (recalculated } \\
\text { survival and } \\
\text { branch loss) }\end{array}$ & $\begin{array}{l}\text { Survival } \\
(\%)\end{array}$ & $\begin{array}{l}\text { Recalculated } \\
\text { survival }(\%)\end{array}$ & $\begin{array}{l}\text { Branch } \\
\text { loss } \\
(\%)\end{array}$ \\
\hline 0 to 3.5 & $270(224)$ & $90 \mathrm{a}$ & $64 \mathrm{a}$ & $36 \mathrm{a}$ \\
3.6 to 7 & $133(99)$ & $90 \mathrm{a}$ & $73 \mathrm{a}$ & $29 \mathrm{a}$ \\
$>7$ & $98(70)$ & $98 \mathrm{a}$ & $91 \mathrm{~b}$ & $20 \mathrm{~b}$ \\
\hline
\end{tabular}

${ }^{\mathrm{z}}$ Numbers in columns with different letters are significantly different at $P=$ $0.05)$. cedar. Survival for pruned trees was $73 \%$ compared with $47 \%$ for unpruned trees $(P=0.0001)$.

\section{The Survey}

Arborists, urban foresters, and scientists confirmed many of our results about wind resistance but also provided some new information about some species not so frequently seen and measured in the urban forest. Consistent with our results, queen palm was ranked by the experts as the palm with the lowest wind resistance (Table 4). Royal palm and coconut palm were intermediate, again consistent with our results. Sabal palm was ranked high, which is consistent with our results from the tropical and northern areas of Florida (Duryea et al. 1996; Duryea 1997; Duryea et al. 2007). Some of the species with little information from our studies that were ranked high by the experts include pond apple (Annona glabra), cocoplum (Chrysobalanus icaco), and lignum vitae (Guaiacum sanctum). Species with little research information that were ranked with low wind resistance include weeping banyan, jacaranda (Jacaranda mimosifolia), and golden trumpet (Tabebuia chrysotricha). Species ranked with high wind resistance in agreement with our results were crapemyrtle (Lagerstroemia indica), dahoon holly (Ilex cassine), southern magnolia (Magnolia grandiflora), sand live oak, live oak, and both species of cypress (Taxodium distichum and T. ascendens). One perplexing species is West Indian mahogany, which fared reasonably well in Georges and Andrew (Table 1); however, the survey respondents ranked it with medium to low wind resistance. In agreement with our results but in contrast to the survey results, in another study of 24 species experiencing Hurricane Georges, West Indian mahogany had the best survival and the least branch loss (Francis 2000).

\section{IMPLICATIONS FOR ARBORICULTURE AND URBAN FORESTRY}

Taking the results from our studies and incorporating the survey results and the scientific literature, we have developed lists of relative wind resistance for tropical and subtropical tree species (Figure 4). These lists should be used with caution with the knowledge that no species and no tree is completely windproof and with the consideration of local soil conditions, tree age, structure and health, and other urban forest conditions. In their thorough review of forest damage from wind, Everham and Brokaw (1996) concluded that species differences do exist and can be explained by differences in wood density, canopy architecture, rooting patterns, susceptibility to diseases, and bole shape. Yet these differences, they say, can also be masked by varied soil conditions, exposure, wind intensity, and cultural practices. Some of the other practices and conditions of the urban forest and their associated recommendations are:

- One of the most important findings and therefore recommendations from this study are the rooting space results. It is clear that the more rooting space that a tree 
Table 4. Results of the survey of arborists, scientists, and urban foresters in Florida with their rankings for wind resistance of tropical and subtropical tree species².

\begin{tabular}{|c|c|c|c|c|c|c|c|c|c|}
\hline \multirow[b]{3}{*}{ Scientific name } & \multirow[b]{3}{*}{ Common name } & \multicolumn{6}{|c|}{ Wind resistance } & \multirow[b]{3}{*}{$P$ Value } & \multirow[b]{3}{*}{ Total $n$} \\
\hline & & \multicolumn{2}{|c|}{ High } & \multicolumn{2}{|c|}{ Medium } & \multicolumn{2}{|c|}{ Low } & & \\
\hline & & $\mathrm{n}$ & Percent & $\mathrm{n}$ & Percent & $\mathrm{n}$ & Percent & & \\
\hline \multicolumn{10}{|l|}{ Dicots } \\
\hline Acer rubrum & Red maple & 12 & 20 & 32 & 52 & 17 & 28 & 0.0049 & 61 \\
\hline Annona glabra & Pond apple & 10 & 71 & 4 & 29 & 0 & 0 & NS & 14 \\
\hline Araucaria heterophylla & Norfolk Island pine & 8 & 18 & 14 & 31 & 23 & 51 & 0.0224 & 45 \\
\hline Averrhoa carambola & Star-fruit or carambola & 3 & 18 & 6 & 35 & 8 & 47 & NS & 17 \\
\hline Bauhinia blakeana & Hong Kong orchid & 1 & 5 & 9 & 41 & 12 & 54 & 0.0122 & 22 \\
\hline Bucida buceras & Black olive & 8 & 30 & 14 & 52 & 5 & 18 & 0.0538 & 27 \\
\hline Bursera simarouba & Gumbo limbo & 21 & 64 & 10 & 30 & 2 & 6 & 0.0007 & 33 \\
\hline Callistemon spp. & Bottlebrush & 8 & 21 & 23 & 61 & 7 & 18 & 0.0018 & 38 \\
\hline \multicolumn{10}{|l|}{ Calophyllum calaba } \\
\hline$\left({ }^{\mathrm{x}}\right.$ in $\left.\mathrm{s} . \mathrm{FL}\right)$ & Brazilian beautyleaf & 6 & 38 & 8 & 50 & 2 & 12 & NS & 16 \\
\hline Cassia fistula & Golden shower & 4 & 18 & 7 & 32 & 11 & 50 & NS & 22 \\
\hline Ceiba (or Chorisia) speciosa & Floss-silk & 4 & 18 & 12 & 55 & 6 & 27 & 0.0498 & 22 \\
\hline Chrysobalanus icaco & Cocoplum & 18 & 78 & 5 & 22 & 0 & 0 & 0.0067 & 23 \\
\hline Chrysophyllum oliviforme & Satinleaf & 11 & 61 & 7 & 39 & 0 & 0 & NS & 18 \\
\hline Citrus spp. & Citrus (e.g., lime, orange) & 18 & 44 & 18 & 44 & 5 & 12 & 0.0162 & 41 \\
\hline Coccoloba diversifolia & Pigeon plum & 11 & 58 & 8 & 42 & 0 & 0 & NS & 19 \\
\hline Coccoloba uvifera & Sea grape & 18 & 50 & 12 & 33 & 6 & 17 & 0.0498 & 36 \\
\hline Conocarpus erectus & Buttonwood & 11 & 35 & 17 & 55 & 3 & 10 & 0.0084 & 31 \\
\hline Cordia sebestena & Geiger tree & 8 & 33 & 13 & 54 & 3 & 12 & 0.0439 & 24 \\
\hline$\times$ Cupressocyparis leylandii & Leyland cypress & 7 & 22 & 13 & 41 & 12 & 37 & NS & 32 \\
\hline Delonix regia $\left({ }^{\mathrm{x}}\right.$ in $\left.\mathrm{S} . \mathrm{FL}\right)$ & Royal poinciana & 2 & 6 & 20 & 63 & 10 & 31 & 0.0005 & 32 \\
\hline Enterolobium cyclocarpum & Ear tree & 1 & 5 & 7 & 33 & 13 & 62 & 0.0058 & 21 \\
\hline \multicolumn{10}{|l|}{ Eriobotrya japonica } \\
\hline ( ${ }^{\mathrm{x}}$ in central and s. FL) & Loquat & 9 & 24 & 24 & 63 & 5 & 13 & 0.0004 & 38 \\
\hline Eucalyptus cinerea & Silver dollar eucalyptus & 2 & 13 & 9 & 56 & 5 & 31 & NS & 16 \\
\hline Eugenia axillaris & White stopper & 7 & 64 & 3 & 27 & 1 & 9 & NS & 11 \\
\hline Eugenia foetida & Boxleaf, Spanish stopper & 7 & 64 & 2 & 18 & 2 & 18 & NS & 11 \\
\hline Ficus aurea & Strangler fig & 4 & 36 & 5 & 46 & 2 & 18 & NS & 11 \\
\hline Ficus benjamina & Weeping banyan & 0 & 0 & 2 & 18 & 9 & 82 & 0.0348 & 11 \\
\hline Grevillea robusta & Silk oak & 1 & 4 & 8 & 32 & 16 & 64 & 0.0012 & 25 \\
\hline Guaiacum sanctum & Lignumvitae & 10 & 83 & 2 & 17 & 0 & 0 & 0.0209 & 12 \\
\hline Ilex cassine & Dahoon holly & 35 & 76 & 10 & 22 & 1 & 2 & 0.0001 & 46 \\
\hline Jacaranda mimosifolia & Jacaranda, black poui & 1 & 7 & 2 & 13 & 12 & 80 & 0.0006 & 15 \\
\hline Juniperus silicicola & SE redcedar & 14 & 28 & 18 & 35 & 19 & 37 & NS & 51 \\
\hline Kigelia pinnata & Sausage tree & 7 & 41 & 6 & 35 & 4 & 24 & NS & 17 \\
\hline Koelreuteria paniculata & Golden raintree & 11 & 37 & 11 & 37 & 8 & 26 & NS & 30 \\
\hline Krugiodendron ferreum & Ironwood & 10 & 77 & 3 & 23 & 0 & 0 & NS & 13 \\
\hline Lagerstroemia indica & Crapemyrtle & 55 & 83 & 11 & 17 & 0 & 0 & 0.0001 & 66 \\
\hline Ligustrum japonicum & Privet & 30 & 75 & 9 & 23 & 1 & 2 & 0.0001 & 40 \\
\hline Liquidambar styraciflua & Sweetgum & 19 & 43 & 22 & 50 & 3 & 7 & 0.0013 & 44 \\
\hline Litchi chinensis & Lichee & 8 & 57 & 5 & 36 & 1 & 7 & NS & 14 \\
\hline Lysiloma latisiliqua & Wild tamarind & 9 & 50 & 6 & 33 & 3 & 17 & NS & 18 \\
\hline Magnolia grandiflora & SE magnolia & 45 & 82 & 9 & 16 & 1 & 2 & 0.0001 & 55 \\
\hline Mangifera indica & Mango tree & 6 & 20 & 16 & 53 & 8 & 27 & NS & 30 \\
\hline Peltophorum pterocarpa & Yellow poinciana & 1 & 5 & 15 & 68 & 6 & 27 & 0.0010 & 22 \\
\hline Persea americana & Avocado tree & 1 & 3 & 20 & 63 & 11 & 34 & 0.0002 & 32 \\
\hline Pinus clausa & Sand pine & 3 & 7 & 7 & 16 & 34 & 77 & 0.0001 & 44 \\
\hline Pinus elliottii var. densa & FL slash pine & 18 & 38 & 25 & 52 & 5 & 10 & 0.0016 & 48 \\
\hline Pinus palustris & Longleaf pine & 23 & 56 & 13 & 32 & 5 & 12 & 0.0017 & 41 \\
\hline Podocarpus spp. & Podocarpus & 24 & 75 & 7 & 22 & 1 & 3 & 0.0001 & 32 \\
\hline
\end{tabular}


Table 4. Results of the survey of arborists, scientists, and urban foresters in Florida with their rankings for wind resistance of tropical and subtropical tree species ${ }^{2}$. (continued)

\begin{tabular}{|c|c|c|c|c|c|c|c|c|c|}
\hline \multirow[b]{3}{*}{ Scientific name } & \multirow[b]{3}{*}{ Common name } & \multicolumn{6}{|c|}{ Wind resistance } & \multirow[b]{3}{*}{$P$ Value } & \multirow[b]{3}{*}{ Total $n$} \\
\hline & & \multicolumn{2}{|c|}{ High } & \multicolumn{2}{|c|}{ Medium } & \multicolumn{2}{|c|}{ Low } & & \\
\hline & & $\mathrm{n}$ & Percent & $\mathrm{n}$ & Percent & $\mathrm{n}$ & Percent & & \\
\hline Prunus caroliniana & Carolina laurel cherry & 5 & 16 & 15 & 48 & 11 & 36 & NS & 31 \\
\hline Quercus geminata & Sand live oak & 36 & 92 & 2 & 5 & 1 & 3 & 0.0001 & 39 \\
\hline Quercus laurifolia & Laurel oak & 3 & 4 & 27 & 39 & 39 & 57 & 0.0001 & 69 \\
\hline Quercus nigra & Water oak & 3 & 8 & 14 & 36 & 22 & 56 & 0.0009 & 39 \\
\hline Quercus stellata & Post oak & 5 & 33 & 10 & 67 & 0 & 0 & NS & 15 \\
\hline Quercus virginiana & Live oak & 64 & 89 & 8 & 11 & 0 & 0 & 0.0001 & 72 \\
\hline Sideroxylon foetidissimum & Mastic tree & 3 & 30 & 6 & 60 & 1 & 10 & NS & 10 \\
\hline Simarouba glauca & Paradise tree & 5 & 42 & 5 & 42 & 2 & 16 & NS & 12 \\
\hline Spathodea campanulata & African tuliptree & 0 & 0 & 6 & 38 & 10 & 62 & NS & 16 \\
\hline Swietenia mahagoni & West Indian mahogany & 2 & 9 & 13 & 56 & 8 & 35 & NS & 23 \\
\hline Tabebuia aurea & Silver trumpet & 0 & 0 & 4 & 33 & 8 & 67 & NS & 12 \\
\hline Tabebuia chrysotricha & Golden trumpet & 2 & 7 & 5 & 18 & 21 & 75 & 0.0001 & 28 \\
\hline Tabebuia heterophylla & Pink trumpet, white cedar & 0 & 0 & 6 & 55 & 5 & 45 & NS & 11 \\
\hline Tabebuia impetiginosa & Purple tabebuia, ipe & 3 & 12 & 12 & 50 & 9 & 38 & NS & 24 \\
\hline Tecoma stans & Yellow elder & 0 & 0 & 8 & 73 & 3 & 27 & NS & 11 \\
\hline \multicolumn{10}{|l|}{ Terminalia catappa } \\
\hline$\left({ }^{\mathrm{x}}\right.$ in south FL) & Tropical almond & 3 & 20 & 8 & 53 & 4 & 27 & NS & 15 \\
\hline Taxodium distichum & Baldcypress & 59 & 91 & 6 & 9 & 0 & 0 & 0.0001 & 65 \\
\hline Taxodium ascendens & Pond cypress & 41 & 91 & 4 & 9 & 0 & 0 & 0.0001 & 45 \\
\hline \multicolumn{10}{|l|}{ Palms } \\
\hline Butia capitata & Pindo & 34 & 79 & 7 & 16 & 2 & 5 & 0.0001 & 43 \\
\hline Caryota mitis & Fishtail & 8 & 38 & 6 & 29 & 7 & 33 & NS & 21 \\
\hline Chrysalidocarpus lutescens & Areca & 19 & 63 & 11 & 37 & 0 & 0 & NS & 30 \\
\hline Coccothrinax argentata & FL silver, silver thatch & 21 & 95 & 1 & 5 & 0 & 0 & 0.0001 & 22 \\
\hline Cocos nucifera & Coconut & 22 & 63 & 13 & 37 & 0 & 0 & NS & 35 \\
\hline Hyophorbe lagenicaulis & Bottle & 13 & 81 & 3 & 19 & 0 & 0 & 0.0124 & 16 \\
\hline Hyophorbe verschaffeltii & Spindle & 11 & 79 & 2 & 14 & 1 & 7 & 0.0015 & 14 \\
\hline Latania loddigesii & Blue latan & 8 & 67 & 3 & 25 & 1 & 8 & 0.0388 & 12 \\
\hline \multicolumn{10}{|l|}{ Livistona chinensis $\left({ }^{\mathrm{x}}\right.$ in central } \\
\hline Neodypsis decaryi & Triangle & 14 & 58 & 6 & 25 & 4 & 17 & 0.0302 & 24 \\
\hline Phoenix canariensis & Canary Island date & 49 & 89 & 4 & 7 & 2 & 4 & 0.0001 & 55 \\
\hline Phoenix dactylifera & Date & 33 & 94 & 2 & 6 & 0 & 0 & 0.0001 & 35 \\
\hline \multicolumn{10}{|l|}{ Phoenix reclinata } \\
\hline ( ${ }^{\mathrm{y}}$ in south FL) & Senegal date & 29 & 85 & 5 & 15 & 0 & 0 & 0.0001 & 34 \\
\hline Phoenix roebelenii & Pygmy date & 40 & 98 & 1 & 2 & 0 & 0 & 0.0001 & 41 \\
\hline Ptychosperma elegans & Alexander, solitary & 16 & 73 & 6 & 27 & 0 & 0 & 0.0330 & 22 \\
\hline Roystonea elata & Florida royal & 19 & 56 & 10 & 29 & 5 & 15 & 0.0118 & 34 \\
\hline Roystonea regia & Cuban royal & 17 & 61 & 10 & 36 & 1 & 4 & 0.0010 & 28 \\
\hline Sabal palmetto & Cabbage & 71 & 99 & 1 & 1 & 0 & 0 & 0.0001 & 72 \\
\hline Syagrus romanzoffiana & Queen & 5 & 10 & 17 & 33 & 29 & 57 & 0.0002 & 51 \\
\hline Thrinax morrisii & Key thatch & 13 & 87 & 2 & 13 & 0 & 0 & 0.0045 & 15 \\
\hline Thrinax radiata & Florida thatch & 17 & 89 & 2 & 11 & 0 & 0 & 0.0006 & 19 \\
\hline Veitchia merrillii & Manila, Christmas & 13 & 81 & 3 & 19 & 0 & 0 & 0.0124 & 16 \\
\hline Washingtonia robusta & Washington fan & 29 & 54 & 16 & 30 & 9 & 17 & 0.0033 & 54 \\
\hline
\end{tabular}

${ }^{z} n$ is the number of respondents for each species out of a total of 85 experts. $P$ values from the $\chi^{2}$ test for equal proportions indicate the significance level for one or more of the categories being different from the others; NS means that there is no significant difference between the categories of high, medium, and low $(P>0.05)$.

y Invasive and not recommended for use in Florida.

${ }^{\mathrm{x}}$ Caution: may be used but manage to prevent escape in Florida (Fox et al. 2005). 


\section{Highest Wind Resistance}

Dicots

> Bursera sinaruba, gumbo limbo

> Carya floridana, FL scrub hickory

$>\quad$ Conocarpus erectus, buttonwood

- Chrysobalanus icaco, cocoplum

$>\quad$ Cordia sebestena, geiger tree

$>\quad$ Eugenia axillaris, white stopper

- Eugenia confusa, redberry

- Eugenia foetida, boxleaf stopper

> Guaiacum sanctum, lignum vitae

- Hex cassine, dahoon holly

> Kruglodendron ferreum, ironwood

> Lagerstroemia indica, crape myrtle

> Magnolia grandiflora, southern magnolia

- Podocarpus spp., podocarpus

$>\quad$ Quercus vinginiana, live oak

$>\quad$ Quercus geminata, sand live oak

Conifers

$>\quad$ Taxodium distichum, baldcypress

$>\quad$ Taxodium ascendens, pondeypress

Palms

$>\quad$ Adonidia merrillii, Manila

$>\quad$ Butia capitata, pindo

$>\quad$ Dypsis lutescens, areca

$>$ Coccothrinax argentata, FL silver

> Hyophorbe lagenicaulis, bottle

$>\quad H y o p h o r b e$ verschaffelti, spindle

$>\quad$ Latania foddigesii, blue latan

$>\quad$ Livistona chinensis, Chinese fan $* * *$

- Phoenix canariensis, Canary Island date

$>$ Phoenix dactylifera, date

$>$ Phoenix rectinata, Senegal date ${ }^{* *}$

$>\quad$ Phoenix roebelenii, pygmy date

$>\quad$ Ptychosperma elegans, Alexander

$>\quad$ Sabal palmetto, cabbage

- Thrinax morrisï, key thatch

$>\quad$ Thrinax radiata, Florida thatch

\section{Medium-High Wind Resistance}

Dicots

> Annona glabra, pond apple

$>$ Calophyllum antillanum, Brazilian beautyleaf $* * *$

$>$ Chrysophyllum oliviforme, satinleaf

$>$ Coccoloba uvifera, sea grape

$>$ Coccoloba diversifolia, pigeon plum

> Liquidambar styraciflua, sweetgum

$>\quad$ Lysiloma latisiliquum, false tamarind

> Magnolia virginiana, sweetbay magnolia

- Nyssa sylvatica, black tupelo

$>\quad$ Sideroxylon foetidissimum, mastic tree

$>\quad$ Simarouba glauca, paradise tree

$>\quad$ Swietenia mahagoni, mahogany

Palms

- Caryota mitis, fishtail

$>$ Cocos nucifera, coconut

$>\quad$ Dypsis decaryl, triangle

> Roystonea elata, royal

Fruit Trees

> Litchi chinensis, lychee

Figure 4. Relative wind resistance ratings of tropical/subtropical tree species as estimated using the results from this hurricane study, the expert survey results of this study, and the scientific literature cited throughout this article.

has, the healthier it is and this means better anchorage and resistance to wind.

- Another important cultural practice for broad-leaved trees is pruning. Pruning conferred more wind resistance to trees and should be considered an important practice for tree health and wind resistance.

- Trees growing in groups or clusters were also more wind-resistant compared with individual trees. This might be an especially good strategy for tree establishment in parks or larger yards.

- Especially in south Florida, native trees appear to survive winds better than exotics. When considering species to plant, it is especially important to know the exotic species that do not fare well in wind; some of these include melaleuca, Australian pine, queen palm, African tulip tree, and weeping banyan. 


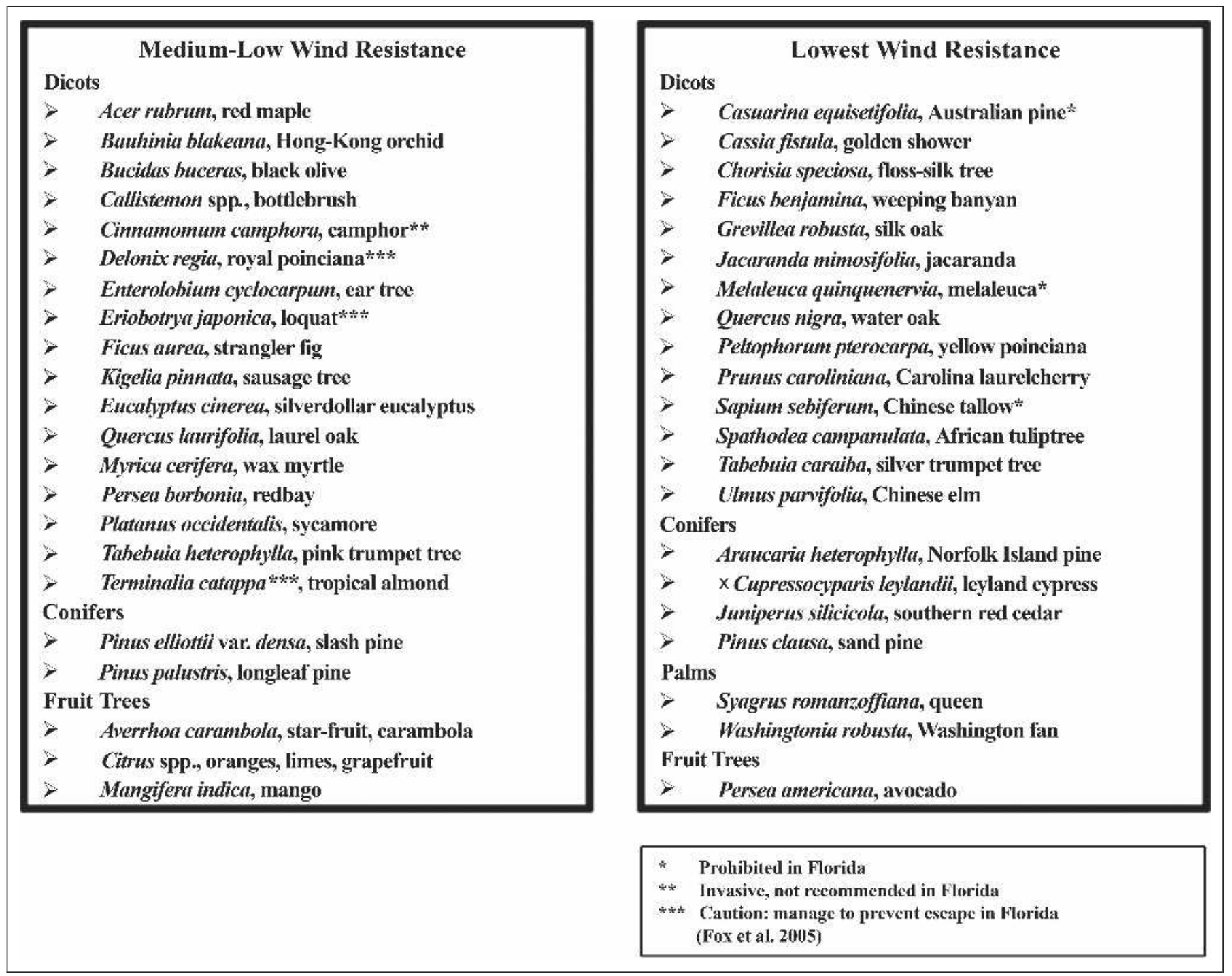

Figure 4. (continued)

Acknowledgments. This project was partially funded by the Florida Department of Transportation. We are grateful to Jeff English and Meghan Brennan for help in the field and during the statistical analyses and to Rick Joyce for his support of this study.

\section{LITERATURE CITED}

Barry, P.J., C. Doggett, R.L. Anderson, and K.M. Swain Sr. 1993. How to evaluate and manage storm-damaged forest areas. Management Bulletin R8-MB 63 of the USDA Forest Service, Southern Region. Atlanta, GA. 11 pp.

Curtis, J.D. 1943. Some observations on wind damage. Journal of Forestry 41:877-882.

Duryea, M.L. 1997. Wind and trees: Surveys of tree damage in the Florida Panhandle after Hurricanes Erin and Opal. Circular 1183 of the University of Florida Cooperative
Extension Service. http://edis.ifas.ufl.edu/ (accessed 3/8/ 06). Gainesville, FL. 7 pp.

Duryea, M.L., G.M. Blakeslee, W.G. Hubbard, and R.A. Vasquez. 1996. Wind and trees: A survey of homeowners after Hurricane Andrew. Journal of Arboriculture 22: 44-50.

Duryea, M.L., E. Kampf, and R.C. Littell. 2007. Hurricanes and the Urban Forest: I. Effects on Southeastern U.S. Coastal Plain Tree Species. Arboriculture \& Urban Forestry 33:83-97.

Everham, E.M. III, and N.V.L. Brokaw. 1996. Forest damage and recovery from catastrophic wind. Botanical Review 62:113-185.

Forest Products Laboratory. 1999. Wood handbook-Wood as an engineering material. Gen. Tech. Rep. FPL-GTR- 
113 of the USDA Forest Service Forest Products Laboratory. Madison, WI. 463 pp.

Fox, A.M., D.R. Gordon, J.A. Dusky, L. Tyson, and R.K. Stocker. 2005. IFAS assessment of the status of nonnative plants in Florida's natural areas. SS-AGR-225 of the University of Florida IFAS Cooperative Extension Service. http://plants.ifas.ufl.edu/assessment.html (accessed 3/8/06). Gainesville, FL. 27 pp.

Francis, J.K. 2000. Comparison of hurricane damage to several species of urban trees in San Juan, Puerto Rico. Journal of Arboriculture 26:189-197.

Francis, J.K., and A.J.R. Gillespie. 1993. Relating gust speed to tree damage in Hurricane Hugo, 1989. Journal of Arboriculture 19:368-372.

Frangi, J.L. and A.E. Lugo. 1991. Hurricane damage to a flood plain forest in the Luquillo Mountains of Puerto Rico. Biotropica (Part A. Special Issue: Ecosystem, Plant, And Animal Responses to Hurricanes in the Caribbean) 23:324-335.

Gilman, E. 2005. Tree selection for landscapes. Web site with 680 Tree Fact Sheets: http://hort.ifas.ufl.edu/woody/ planting/TreeSelectionIntroduction.htm (accessed 3/8/06) of the University of Florida Cooperative Extension Service. Gainesville, FL.

Gresham, C.A., T.M. Williams, and D.J. Lipscomb. 1991. Hurricane Hugo wind damage to Southeastern U.S. coastal forest tree species. Biotropica (Part A. Special Issue: Ecosystem, Plant, and Animal Responses to Hurricanes in the Caribbean) 23:420-426.

Harris, R.W., J.R. Clark, and N.P. Matheny. 2004. Arboriculture: Integrated Management of Landscape Trees, Shrubs, and Vines. 4th ed. Prentice-Hall, Upper Saddle River, NJ. 580 pp.

Hightshoe, G.L. 1988. Native trees, shrubs, and vines for urban and rural America: A planting design manual for environmental designers. Van Nostrand Reinhold, New York, NY. 819 pp.

Hook, D.D., M.A. Buford, and T.M. Williams. 1991. Impact of Hurricane Hugo on the South Carolina coastal plain forest. Journal of Coastal Research (Special issue) 8:291-300.

Jim, C.Y., and H.H.T. Liu. 1997. Storm damage on urban trees in Guangzhou, China. Landscape and Urban Planning 38:45-59.

King, D.A. 1986. Tree form, height growth, and susceptibility to wind damage in Acer saccharum. Ecology 67:980-990.

Niklas, K.J. 1999. Changes in the factor of safety within the superstructure of a dicot tree. American Journal of Botany 86:688-696.

- 2002. Wind, size, and tree safety. Journal of Arboriculture 28:81-89.

Niklas, K.J., and H.-C. Spatz. 2000. Wind-induced stresses in cherry trees: Evidence against the hypotheses of constant stress levels. Trees (Berlin) 14:230-237.
Orr, D.W., and J.C. Ogden. 1992. The impact of Hurricane Andrew on the ecosystems of south Florida. Conservation Biology 6:488-490.

Platt, W.J., R.F. Doren, and T.V. Armentano. 2000. Effects of Hurricane Andrew on stands of slash pine (Pinus elliottii var. densa) in the everglades region of south Florida (USA). Plant Ecology 146:43-60.

Putz, F.E., P.D. Coley, K. Lu, A. Montalvo, and A. Aiello. 1983. Uprooting and snapping of trees: Structural determinants and ecological consequences. Canadian Journal of Forest Research 13:1011-1020.

Putz, F.E., and R.R. Sharitz. 1991. Hurricane damage to oldgrowth forests in Congaree Swamp National Monument, South Carolina, U.S.A. Canadian Journal of Forest Research 21:1765-1770.

Reyes, G., S. Brown, J. Chapman, and A.E. Lugo. 1992. Wood densities of tropical tree species. Gen. Tech. Rep. SO-88 of the USDA Forest Service Southern Forest Experiment Station. New Orleans, LA. 15 pp.

Skatter, S., and B. Kucera. 2000. Tree breakage from torsional wind loading due to crown asymmetry. Forest Ecology and Management 135:97-103.

Swain, K.M. 1979. Minimizing timber damage from hurricanes. Southern Lumberman 239:107-109.

Touliatos, P., and E. Roth. 1971. Hurricanes and trees: Ten lessons from Camille. Journal of Forestry 69:285-289.

Van Hooser, D.D., and A. Hedlund. 1969. Timber damaged by Hurricane Camille in Mississippi. Research Note SO96 of the USDA Forest Service Southern Forest Experiment Station, New Orleans, LA. 5 pp.

Walker, L.R. 1991. Tree damage and recovery from hurricane Hugo in Luquillo Experimental Forest, Puerto Rico. Biotropica (Part A. Special Issue: Ecosystem, Plant, and Animal Responses to Hurricanes in the Caribbean) 23: 379-385.

Webb, S.L. 1989. Contrasting windstorm consequences in two forests, Itasca State Park, Minnesota. Ecology 70: 1167-1180.

Zimmerman, J.K., E.M. Everham III, R.B. Waide, D.J. Lodge, C.M. Taylor, and N.V.L. Brokaw. 1994. Responses of tree species to hurricane winds in a subtropical wet forest in Puerto Rico: Implications for tropical tree life histories. Journal of Ecology 82:911-922.

Mary L. Duryea (corresponding author)

Professor and Associate Dean

Institute of Food and Agricultural Sciences

University of Florida

P.O. Box 110200

Gainesville, FL 32611-0200, U.S.

mlduryea@ufl.edu 


\author{
Eliana Kampf \\ Urban Forest Research Associate \\ School of Forest Resources and Conservation \\ University of Florida \\ P.O. Box 110831 \\ Gainesville, FL 32611-0831, U.S.
}

Ramon C. Littell

Professor

Department of Statistics

University of Florida

P.O. Box 110339

Gainesville, FL 32611-0339, U.S.

Carlos D. Rodríguez-Pedraza

Ecologist

USDA Forest Service

International Institute of Tropical Forestry

Jardín Botánico Sur

1201 Ceiba Street

San Juan, PR 00926-1119

Résumé. En 1998 lorsque l'ouragan Georges (177 km/h) a traversé complètement l'île de Porto Rico, et en 2004 lorsque les ouragans Jeanne $(193 \mathrm{~km} / \mathrm{h})$ et Charley $(233 \mathrm{~km} / \mathrm{h})$ ont frappé le Sud de la Floride, nous avons alors mesuré les impacts de ces ouragans sur la forêt urbaine composée d'espèces tropicales et subtropicales. De plus, nous avons aussi utilisé des données provenant de l'ouragan Andrew pour certaines analyses. Le pourcentage de perte dans la forêt urbaine a varié de $13 \%$ pour Georges à $16 \%$ pour Jeanne et jusqu'à $18 \%$ pour Charley. Dans les ouragans Jeanne et Charley, les palmiers ont significativement mieux survécu que tous les autres arbres. Certaines des espèces qui ont le mieux survécu lors des ouragans en Floride sont le Bursera simarouba, le Coccoloba uvifera, le Ficus aurea, le Quercus virginiana, le Quercus laurifolia et le Taxodium distichum. Des espèces mesurées à Porto Rico, celles qui ont eu le meilleur taux de survie et le plus faible taux de dommages aux branches ont été le Calophyllum calaba, le Pinus caribaea, le Schefflera actinophylla et le Swietenia mahogani. La perte de feuilles durant ces ouragans n'a eu aucune relation avec le « comment bien » les arbres ont survécu. Lors des ouragans Jeanne, Charley et Georges, $3 \%, 4 \%$ et $11 \%$ des arbres qui sont tombés ont causé des dommages aux propriétés. Les espèces indigènes ont mieux survécu que celles introduites lors des ouragans Jeanne et Charley, mais pas lors de l'ouragan Georges. Les arbres poussant en groupes ont connu un plus haut taux de survie et moins de dommages aux branches lors de l'ouragan Jeanne que ceux poussant individuellement. La densité du bois n'a eu aucun lien avec le taux de survie ou la perte en branches chez les différentes espèces d'arbres lors des ouragans Jeanne, Charley, Georges ou Andrew. Deux autres mesures de la résistance du bois, soient les modules d'élasticité et de rupture, ont été reliés au taux de survie et à la perte de branches dans le cas de l'ouragan Jeanne, mais pas pour Charley. Les espèces d'arbres avec des cimes denses ont eu un taux de survie plus élevé et des pertes en branches plus faibles que celles aux cimes moins denses ou ouvertes. Les espèces d'arbres avec une croissance de forme plus «pyramidale » ont mieux survécu que celles avec une forme plus expansive en hauteur, et ce lors de l'ouragan Jeanne, mais pas dans le cas de Charley où cela n'a eu aucune influence. Les arbres avec la plus grande surface racinaire $\left(>7 \mathrm{~m}^{2}\right)$ ont eu le plus faible taux de perte en branches et le plus haut taux de survie lors de l'ouragan Georges. Une re-analyse de sept espèces et de leur survie lors de l'ouragan Andrew a permis de montrer que le taux de survie des arbres élagués était de $73 \%$ par rapport à $47 \%$ pour les arbres non élagués. Une enquête auprès de 85 arboriculteurs, scientifiques et forestiers urbains a permis de classifier les arbres selon leur degré de résistance au vent. En utilisant les résultats provenant de nos mesures des ouragans et en les incorporant avec ceux provenant de l'inventaire et les données de la littérature scientifique, nous avons développé une liste de résistance relative au vent pour les espèces tropicales et subtropicales. Ces listes sont présentées avec l'avertissement qu'aucun arbre n'est totalement à l'épreuve du vent et que d'autre facteurs tels le sol, les pratiques culturales, l'âge et la santé de l'arbre contribuent aussi au renforcement face au vent.

Zusammenfassung. Als 1998 der Wirbelsturm Georges mit 177 km/h über Puerto Rico fegte und 2004 die Stürme Jeanne mit 193 km/h und Charley mit 233 km/h Windgeschwindigkeit die Südküste von Florida trafen, haben wir die Auswirkungen dieser Stürme auf die urbanen Wälder, bestehend aus tropischen und subtropischen Arten, gemessen. Zusätzlich haben wir noch die publizierten Daten vom Sturm Andrew für einige Analysen hinzugenommen. Der Prozentsatz an Baumverlust betrug $13 \%$ bei Georges, $16 \%$ bei Jeanne und $18 \%$ bei Charley. In den Stürmen Jeanne und Charley überlebten die Palmen mehr als die anderen Baumarten. Einige der Baumarten mit der größten Überlebensrate waren Bursera simarouba, Coccoloba uvifera, Ficus aurea, Quercus virginiana, Quercus laurifolia und Taxodium distichum. Von den Baumarten in Puerto Rico waren die Arten mit der größten Überlebensrate und dem geringsten Astverlust: Calophyllum calaba, Pinus caribaea, Schefflera actinophylla, und Swietenia mahogani. Der Blattverlust während dieser Stürme hatte keine Beziehung zur Überlebensrate. In den Stürmen Jeanne, Charley und Georges schädigten 3\%, 4\% und $11 \%$ der geworfenen Bäume Eigentum. Endemische Baumarten überlebten in den Stürmen Jeanne und Charley mehr als die exotischen Baumarten. Das galt nicht für Georges. Im Sturm Jeanne hatten die Bäume im Gruppenverband eine höhere Überlebensrate als Einzelbäume. In allen vier Stürmen war die Baumdichte nicht verbunden mit der Überlebensrate oder dem Astverlust. Zwei andere Messungen der Holzstärke, die Elastizität und der Brechpunkt, wurden mit dem Überleben und dem Astbruch während des Sturmes Jeanne in Beziehung gebracht. Die Baumarten mit dichten Kronen hatten eine größere Überlebensrate und weniger Astverlust als die Bäume mit offenen Kronen. Baumarten mit geschlossener Kronenform überlebten besser als Bäume mit lockeren Kronen. Das traf zu für die Stürme Jeanne und Charley. Die Bäume mit der größten Wurzelfläche $\left(>7 \mathrm{~m}^{2}\right)$ hatten den geringsten Astverlust und die größte Überlebensrate während des Sturmes Georges. Eine ReAnalyse von sieben dicotylen Baumarten und ihr Überleben während des Sturmes Andrew zeigte, dass das Überleben von geschnittenen Bäumen bei $73 \%$ gegenüber $47 \%$ bei unbeschnittenen Bäumen lag. Eine Umfrage unter 85 Arboristen, Wissenschaftlern und Forstleuten bewertete Baumarten bezüglich ihrer Windresistenz. 
Anhand der erhobenen Sturm-Daten, der Ergebnisse der Umfrage und der wissenschaftlichen Literatur entwickelten wir eine windresistenter Baumarten für tropische und subtropische Arten. Diese Listen werden unter dem Vorbehalt präsentiert, dass kein Baum vollständig windresistent und andere Faktoren, wie Bodenbedingungen, Windintensitäten, Kulturformen und Baumgesundheit und -alter ebenso in Betracht gezogen werden müssen.

Resumen. En 1998 cuando el Huracán Georges (177km/h) pasó sobre la isla de Puerto Rico, y en el 2004 cuando los Huracanes Jeanne $(193 \mathrm{~km} / \mathrm{h})$ y Charley $(233 \mathrm{~km} / \mathrm{h})$ golpearon el sur de la Florida, se midió el impacto de estos huracanes en el bosque urbano compuesto de especies tropicales y subtropicales. Además, para este análisis, se usaron también datos previos publicados del Huracán Andrew. El por ciento de pérdida de bosque urbano estuvo desde $13 \%$ para Georges, $16 \%$ para Jeanne a $18 \%$ para Charley. En los Hurcanes Jeanne y Charley, las palmas supervivieron significativamente mejor que todos los otros árboles. Algunas de las especies que mejor supervivieron en los huracanes de Florida fueron bursera (Bursera simarouba), uva marina (Coccoloba uvifera), higo (Ficus aurea), encino (Quercus virginiana), encino laurel (Quercus laurifolia) y ahuehuete (Taxodium distichum). De las otras especies medidas en Puerto Rico, las de más alta supervivencia y menor pérdida de ramas fueron Santa Maria (Calophyllum calaba), pino del caribe (Pinus caribaea), schefflera (Schefflera actinophylla), y caoba (Swietenia mahogani). La pérdida de ramas durante estos huracanes no tuvo relación con la supervivencia de los árboles. En los Huracanes Jeanne, Charley y Georges, 3\%, 4\%, y $11 \%$ de los árboles que cayeron dañaron propiedades. Las especies nativas supervivieron mejor que las especies exóticas en los Huracanes Jeanne y Charley pero no en el Huracán Georges. Los árboles que crecieron en grupos tuvieron más alta supervivencia y menor pérdida de ramas en el Huracán Jeanne que los que crecieron individualmente. La densidad de la madera no estuvo relacionada a la supervivencia o pérdida de ramas para las especies de árboles en los Huracanes Jeanne, Charley, Georges o Andrew. Otras dos mediciones de resistencia de la madera, módulos de elasticidad y de ruptura, estuvieron relacionados con la supervivencia y pérdida de ramas en Jeanne pero no en Charley. Las especies de árboles con copas densas tuvieron mayor supervivencia y menor pérdida de ramas que las especies de copas menos densas o abiertas. Las especies con crecimiento de forma decurrente supervivieron mejor que los árboles excurrentes en el Huracán Jeanne, sin diferencia en Charley. Los árboles con mayor espacio de raíces $\left(>7 \mathrm{~m}^{2}\right)$ tuvieron la más baja pérdida de ramas y la mayor supervivencia en el Huracán Georges. Un re-análisis de siete especies dicotiledóneas y su supervivencia en el Huracán Andrew mostró que la supervivencia para árboles podados fue $73 \%$ comparada con $47 \%$ para árboles no podados. Una encuesta de 85 arboristas, científicos y dasónomos urbanos clasificó las especies por su resistencia al viento. Utilizando estos resultados de los huracanes e incorporándolos a los de la encuesta y la literatura científica, se desarrollaron listas de especies tropicales y subtropicales relativamente resistentes a los vientos. Estas listas están publicadas con la advertencia de que los árboles no son completamente a prueba de vientos y otros factores como condiciones del suelo, intensidad del viento, prácticas culturales, salud y edad del árbol, también contribuyen a la resistencia al viento. 